DOI: $10.17516 / 1997-1370-0660$

УДК $159.9+316.6$

\title{
Specifics of the Attitude of Students with Deviant Behaviour to School Mediation Service
}

\author{
Olga O. Andronnikova and Olga E. Radzikhovskaya* \\ Novosibirsk State Pedagogical University \\ Novosibirsk, Russian Federation
}

Received 25.05.2020, received in revised form 01.09.2020, accepted 07.09.2020

\begin{abstract}
This article discusses the perception of the effectiveness of school mediation services by adolescents with deviant behaviour. The research was based on Russian speaking adolescents aged 13-17 years (128 interviewees, including 78 girls and 50 boys). The questionnaire was developed in compliance with similar researches using expert evaluation. The results of the research are analyzed as per the Pearson correlation coefficient. The analysis of the difference in the perception of the effectiveness of mediation practices by a group directly involved in the implementation of mediation practices (group 2 of 40 persons) and a group with no direct experience of mediation (group 1 of 88 persons) resulted in some conclusions. The participants of group 2 consider the mediation method an effective means of resolving conflicts, increasing interpersonal skills, and respect for the interlocutor. Mediation is also an effective means of selfdevelopment and self-understanding for group 2. Group 1 displays infantile expectations of mediation effects and high sensitivity to fairness.
\end{abstract}

Keywords: mediation, deviant behaviour, adolescents, interpersonal relations, conflict competence, victimization, education.

Research area: education.

Citation: Andronnikova, O.O., Radzikhovskaya, O.E. (2020). Specifics of the attitude of students with deviant behaviour to school mediation service. J. Sib. Fed. Univ. Humanit. Soc. Sci., 13(9), 1517-1528. DOI: 10.17516/1997-1370-0660.

(C) Siberian Federal University. All rights reserved

* Corresponding author E-mail address: andronnikova_69@mail.ru, o.radzihovskaya@gmail.com

ORCID: 0000-0002-1756-7682 (Andronnikova); 0000-0002-9282-2997 (Radzikhovskaya) 


\section{Introduction}

Children and adolescents with deviant behaviour are often involved in conflicts, become violators or victims. The severity of the problem of countering the juveniles' deviant and victimized behaviour is not reduced. To a large extent, the juveniles' deviant behaviour is the basis for the emergence of criminal behaviour in adulthood, which raises the extremely acute issues of timely intervention. The emergence of conflicts in the educational environment is inevitable, but the current forms of solving school conflicts often do not produce the expected effects. Conflicts remain unresolved, and conflict participants experience a whole range of negative feelings (resentment, anger, frustration, and a sense of injustice), the intensity of which does not decrease over time (Boulton, Boulton, 2011). For children and adolescents whose personal characteristics or conditions of social upbringing are factors of deviance, the experience of such feelings can become the basis for violation of social norms, conflictogenic behaviour, or strengthening the state of helplessness and fixation in a victim's role.

The need for peaceful conflict resolution in an educational organization has resulted in the need for the development of school mediation services aimed at both conflict resolution and teaching students a non-conflict interaction and competences in solving emerging interpersonal difficulties (Amador Buenabad et al., 2020). The use of restorative mediation practices in school allows the participants to get rid of negative experiences, learn to express feelings and emotions, independently resolve the situation (including compensation for damage), and reach an agreement, avoiding any repetition in the future.

\section{Theoretical Framework}

Restorative mediation practices emerged in schools in response to the need for anti-bullying and anti-violence programmes at the beginning of this century. Among the works aimed at finding the ways to prevent conflicts, bullying and organizing school life, there are many empirical and theoretical studies that show the effectiveness and specificity of using mediation programmes (García-Raga, Bo Bonet, Boqué
Torremorell, 2016; Tucker, Maunder, 2015; Pulido, Martín-Seoane, Lucas-Molina, 2013).

Analyzing various aspects of the effectiveness of school mediation services, the researchers note several important parameters. According to Puig-Gutiérrez \& Morales-Lozano (2015), participation in mediation contributes to the development of students' activity, strengthens their ability to interpersonal communication, and stimulates the adequacy of perceiving the issues of justice. Munné \& Mac-Cragh (2006) claim an increase in decision-making and dialogue-building skills among the students involved in mediation processes. García-Raga et al. (2016) consider the educational potential of mediation, as it affects the development of its participants' personalities, the improvement of interpersonal relationships and school microclimate.

It should be noted that the school mediation service is aimed at solving a number of tasks significant for an educational organization. These tasks are implemented through the main functions of the service: a restorative function aimed at conciliatory resolution of existing conflicts; an educational function related to the possibility of using the skill of constructive conflict resolution outside the school; a pedagogical function that forms the students' appropriate values and norms; a preventive function aimed at preventing interpersonal relationships and acquiring the skill of constructive interaction. According to Khabibullin (2018), in Russia, the school mediation service mainly consists of a team of tutors and students who are directly involved in the process of restorative mediation. However, there are other forms of mediation services, including the centres that help educational institutions resolve conflicts. The structure, algorithms, and technologies of mediation recovery work are described in the Russian authors' scientific research (Belonogova, Prokopyeva, 2020; Andronnikova, Radzikhovskaya, 2020, et al.).

Given that educational activities are initially highly conflictogenic, it is conflict prevention that is the leading activity of school mediation (García-Raga, Grau, LópezMartín, 2017; Masharova, 2019). Masharova (2019) notes that in order to achieve a positive 
result in the implementation of reconciliation practices, the mediator has to start with him/ herself, learning to control his/her feelings, reflection, effective communication skills, respect for the interlocutor, and technologies to dampen down an incipient conflict. In addition, when at the meeting the mediator should be able to listen carefully to the participants' opinions, accept their point of view and experiences, and help the participants understand their own emotional states and attitude to what is happening. All this leads to the mediation participants' significant psychological growth and increased competence in interpersonal interaction. The same opinion is shared by Pérez-Albarracín \& Fernández-Baena (2019), who analyzed 157 school mediators. The authors note significant changes in the acquisition of conflict resolution skills and socio-emotional training of mediators themselves in the process of organizing reconciliation. Iriarte \& Ibarrola-García (2018) emphasize the development of the participants' emotional intelligence, social-cognitive skills, and morality in the mediation process.

The expediency of using mediation programmes to prevent the students' deviant behaviour is quite actively discussed in modern science (Sudakova, Koryagina, 2017; Lee, et al., 2020; et al.). Thus, Sudakova, Koryagina (2017) note the increased conflictogenity of the adolescents with deviant and criminal behaviour that requires special technologies to reduce it. The authors refer to school mediation services as an early preventive system for juvenile delinquency. They emphasize the importance of making up for the harm and resolving compensation issues that are necessary for a truly effective resolution of emerging conflicts. For adolescents with anger control problems and deviant behaviour, mediation can be accompanied with anger control training, the effectiveness of which is reflected in the research by Sezen \& Bedel (2015).

In addition to the positive aspects that arise during mediation, it is necessary to note the negative ones that are distinguished by García-Raga, Chiva Sanchís, Moral Mora \& Ramos Santana (2016). These are students' poor training in mediation and a low use of me- diation in resolving conflicts between teachers and students. It is even less often when mediation is used to resolve vertical conflicts between the administration and the teachers as well as conflicts between the teachers themselves.

Currently, in scientific literature, there have appeared the researches on the specifics of organization and effectiveness of school mediation services in different countries of the world (García-Raga, Grau Vidal, Boqué Torremorell, 2019; Pérez-Albarracín, Fernández-Baena, 2019; Lozano-Martín, Gutiérrez-Extremera, Martínez-Martín, 2018). In their cluster-randomized study involving 40 schools, Bonell et al. (2019) claim that mediation technologies have contributed to some improvement in school microclimate as well as in contact between the students with deviant behaviour. Analyzing the results of reconciliation programmes for secondary and high school adolescents, Li, Luo, Zheng et al. (2019) note a decrease in depressive symptoms and anxiety. Gong, Ren, Wu et al. (2019) claim the importance of mediation in reducing cases of non-suicidal self-harm and effectiveness when working with students with a high level of self-criticism.

However, we have not found the researches that would allow us to understand the perception of the effectiveness of school mediation services for students in Russia. This determined the focus of our research aimed at studying the perception of the effectiveness of school mediation services by adolescents with deviant behaviour.

\section{Design and Methodology of the Research}

This research is aimed at analyzing the students' views on the effectiveness and necessity of school mediation, the sample being Russian speaking respondents.

The objectives of the research were to identify the prevalence of school mediation services; to highlight the students' views about the strengths and weaknesses of school mediation; to determine the areas of effective development when participating in school mediation services.

Questions on the students' ideas about school mediation service were drawn up sim- 
ilarly to the questions from García-Raga, Grau Vidal \& Boqué Torremorell's research (2019) and were peer-reviewed (10 experts). In addition, 6 questions were added to identify the inclination to deviant behaviour and risk. Introductory questions related to the interviewees' age, place of residence (a city, a small settlement, and a village), gender, and the views on the mediation service. All the questions in the questionnaire (except for the introductory ones) were of a closed type with two answer options (Yes/No).

The interviewees were teenagers aged from 13 to 17, who answered the questions of the questionnaire published on the Internet and on the site for online research (https:// forms.gle/TCNgEfa5jLAWHbYb9). To avoid adverse effects on the results of the responses certain criteria were introduced. The criteria for selecting the group under the survey were the respondents' age and their experience of contact with the school mediation service (the respondents have participated in the mediation service, there is the mediation service at their school, there is no mediation service at their school, but they know about such a service).

The empirical group consisted of 128 respondents, including $61 \%$ of girls (78 persons) and $39 \%$ of boys (50 persons). There was a certain category of the interviewees with no experience of contacting the mediation service but with some relation to the issue under the discussion. This category included 75 persons who were not among the participants in the common group. Yet, their attitude to the service is given below as an interesting social context.

The mathematical calculation was performed with the SPSS statistical package, version 20.0, which is used for descriptive and logical analysis. The calculations use the Pierson criterion for determining the respondents' ideas on the effectiveness of the school mediation service, both the respondents studying at schools with the mediation service and the respondents studying at schools without such a service but having some experience of contacting the mediation service in other social conditions.

\section{Research results}

A group of the respondents (75 persons) was selected from the total number of all the questionnaire respondents. These respondents did not come into contact with the school mediation service and sometimes did not know what it was. Yet, hypothetically, they had an idea of how useful such a service could be. $62 \%$ of boys and $38 \%$ of girls were among the participants of this group. If they knew nothing about the mediation service, they believed that such a service was unnecessary and would be useless. However, they positively answered all the questions related to mediation as a form of work. Up to $98 \%$ of the respondents in this group gave positive answers to questions 12 , 14, 19, 24 and wrote about the importance of mediation in conflict resolution in their comments. This situation allows us to conclude the necessity to spread information about the mission and technologies of the school mediation service, its mediation function.

Quantitative and qualitative analysis of the results of an empirical group (128 respondents) on their attitude to the school mediation service has revealed the data shown in Table 1.

The results of the questionnaire show that 88 respondents $(68 \%)$ study at schools without the school mediation service, and 40 respondents $(32 \%)$ study at schools with the school mediation service. Undoubtedly, it should be remembered that, according to the research by García-Raga et al. (2019), up to $65.5 \%$ of the respondents studying at schools with the mediation service knew nothing about its activities. This means that some of the respondents, who answered that there is no mediation service in their school, study at schools where such a service is available. However, based on the current situation of self-isolation and collection of the information data via the Internet, there is no way to verify this fact.

The analysis of the specifics of the responses on the effects of the mediation service and its role in changing interpersonal relationships and developing communication skills results in a number of conclusions. Most participants believe that the method of school mediation would reduce the number of sanctions against students and improve the relationship between 
Olga O. Andronnikova and Olga E. Radzikhovskaya. Specifics of the Attitude of Students with Deviant Behaviour...

Table 1. Primary results of the responses to the questionnaire questions

\begin{tabular}{|c|c|c|c|c|}
\hline Questionnaire questions & Yes & Yes $\%$ & No & No\% \\
\hline $\begin{array}{l}\text { 1. The "school mediation" method is used by the students at my school to resolve } \\
\text { conflicts }\end{array}$ & 40 & 31 & 88 & 69 \\
\hline $\begin{array}{l}\text { 2. I believe that the "school mediation" method has helped to reduce the number } \\
\text { of sanctions (punishments, bans) at my school }\end{array}$ & 118 & 92 & 10 & 8 \\
\hline 3. The "school mediation" method has increased the respect among the peers & 58 & 45 & 70 & 55 \\
\hline 4. The "school mediation" method encourages the dialogue between the peers & 33 & 26 & 95 & 74 \\
\hline $\begin{array}{l}\text { 5. Due to the "school mediation" method the relations between students and } \\
\text { teachers have improved }\end{array}$ & 120 & 94 & 8 & 6 \\
\hline $\begin{array}{l}\text { 6. Introduction of the "school mediation" method has reduced the number of } \\
\text { conflicts at school }\end{array}$ & 6 & 5 & 122 & 95 \\
\hline $\begin{array}{l}\text { 7. The "school mediation" method allowed resolving small conflicts that would } \\
\text { eventually turn into more serious problems }\end{array}$ & 10 & 8 & 118 & 92 \\
\hline $\begin{array}{l}\text { 8. Since my school started using the "school mediation" method, the teachers } \\
\text { can better teach their subjects }\end{array}$ & 48 & 38 & 80 & 63 \\
\hline 9. The "school mediation" method has helped me to avoid punishment & 32 & 25 & 96 & 75 \\
\hline 10. The "school mediation" method helped me get out of the problem & 34 & 27 & 94 & 73 \\
\hline 11. The "school mediation" method has helped me learn to communicate better & 58 & 45 & 70 & 55 \\
\hline $\begin{array}{l}\text { 12. Thanks to mediation, I realized my guilt and am ready to eliminate the dam- } \\
\text { age caused }\end{array}$ & 95 & 74 & 33 & 26 \\
\hline 13. I am satisfied with the mediation process & 48 & 38 & 80 & 63 \\
\hline 14. It is through mediation that I have learned to listen to others better & 58 & 45 & 70 & 55 \\
\hline $\begin{array}{l}\text { 15. The "school mediation" method has helped me learn to recognize and ex- } \\
\text { press my feelings }\end{array}$ & 56 & 44 & 72 & 56 \\
\hline 16. The "school mediation" method has helped me to know others better & 49 & 38 & 79 & 62 \\
\hline 17. The "school mediation" method allowed me to get to know myself better & 108 & 84 & 20 & 16 \\
\hline $\begin{array}{l}\text { 18. The "school mediation" method has helped me communicate with others } \\
\text { better }\end{array}$ & 50 & 39 & 78 & 61 \\
\hline $\begin{array}{l}\text { 19. Through mediation I have been considering various ways of conflict reso- } \\
\text { lution }\end{array}$ & 116 & 91 & 12 & 9 \\
\hline 20. The "school mediation" method has improved my creativity & 5 & 4 & 123 & 96 \\
\hline $\begin{array}{l}\text { 21. The "school mediation" method has helped me to be more respectful towards } \\
\text { others }\end{array}$ & 56 & 44 & 72 & 56 \\
\hline $\begin{array}{l}\text { 22. Having become familiar with the "school mediation" method, I could rec- } \\
\text { ommend it to a friend }\end{array}$ & 56 & 44 & 72 & 56 \\
\hline $\begin{array}{l}\text { 23. The skills I have acquired through mediation can be applied to other situa- } \\
\text { tions in my life (family, friends ...) }\end{array}$ & 57 & 45 & 71 & 55 \\
\hline 24. I would like to see more mediation in society & 118 & 92 & 10 & 8 \\
\hline 25. Have there been any violations of legal norms in your life? & 122 & 95 & 6 & 5 \\
\hline 26. Have you ever done anything risky in your life? & 124 & 97 & 4 & 3 \\
\hline 27. Have you ever had an experience of using drugs or alcoholic substances? & 121 & 95 & 7 & 5 \\
\hline 28. Do you smoke? & 86 & 67 & 42 & 33 \\
\hline 29. Have you ever been in an unpleasant situation as a result of your behaviour? & 103 & 80 & 25 & 20 \\
\hline $\begin{array}{l}\text { 30. Do you tend to violate the rules and regulations adopted in your immediate } \\
\text { environment (family, school, ...) }\end{array}$ & 102 & 80 & 26 & 20 \\
\hline
\end{tabular}


students and teachers. However, this form of interaction is not expected to reduce proneness to conflict and increase conflict competence (points 4, 6, 7, 10, 11). Moreover, this method is not considered by the students as a technology for improving communication skills (points $11,14,15,16)$ either. Students are more likely to perceive mediation as a technology of pressure on themselves and forcing them to become aware of guilt (question 19). According to the majority of the participants, the method can be a way to learn how to repair the damage caused. This may be due to the age-specific need for justice, which has peculiar forms in adolescents. In her research Avdulova (2015) claims that violation of faith in a fair world is characteristic for many deviant teenagers. This leads to the formation of an accusatory position with the attitude that for others "the world is fairer". In addition, the author argues that when the faith in the "common fair world" decreases, the faith in the "personal fair world" increases. It is within the latter when fixation on sacrifice and understanding of justice as revenge take place. This sensitivity to justice in adolescents can form a willingness to act "hot on the trail" and constitute a victim's sensitivity that incites the adolescent to self-serving behaviour. According to the research by Nartova-Bochaver \& Astanina (2014), a victim's sensitivity is always destructive for the individual and leads to destructive experiences that will later be expressed in the adolescent's behaviour. This is confirmed by Astanina's research (2017) The scholar claims the offenders' higher sensitivity to justice, which is associated with psychological well-being. This may mean that the extreme value of justice determines the deviant behaviour that occurs in a conflict situation.

Quite often, students regard the method of school mediation as an information resource. The majority of the participants noted that the method of school mediation allowed them to get to know themselves better (point 17) and start thinking about various ways to resolve the conflict (point 19). However, the majority of the respondents are not satisfied with the results of school mediation. This can be explained by the discrepancy between the target orientation of mediation technologies and the expectations of its participants (reduction of sanctions, achieving justice in their understanding, compensation for damage by the abusers, improved interaction with teachers). Therefore, it is clear that the majority of the respondents believe that it is unnecessary to recommend school mediation to friends and that the skills obtained as a result of mediation are not necessary for life and cannot be used in other life situations. It is possible that the difficulties of transferring skills from one area of activity to another may also be related to age characteristics or explained by the adolescents' infantilisation.

To identify the distribution of the responses between the groups of the respondents from schools with the mediation service and from schools where such service is not available the correlation criterion was used to process and calculate the results. The significant differences in the questionnaire questions between the groups are shown in Table 2.

\section{Discussion}

It should be noted that for questions 2-8 about the effectiveness of the school mediation service in organizing the educational process and improving interpersonal interaction between the participants in the educational process there is a significant difference in the answers of the groups.

Group 1 (the participants of the group had no direct experience in mediation practices) have more optimistic expectations of the work of the service on several issues. The respondents reliably expect it to have such effects as the reduction of certain sanctions (punishments, bans) at school and the improvement of the relations between students and teachers. Students in group 2 who have some experience of direct participation in the reconciliation service do not expect any reduction in sanctions. Yet, they note such effects as increasing respect among the peers (point 3) and encouraging the dialogue between the peers (point 4). It is worth while mentioning that mediation practices were highly evaluated as the resources for conflict resolution (questionnaire questions 7 , 19) in group 2, whereas group 1 do not consider the school mediation method as one that reduces conflicts. 
Table 2. Significant differences in responses to the questionnaire questions in the groups of the respondents from schools with the mediation service (group 2) and the respondents from schools without the mediation service (group 1)

\begin{tabular}{|c|c|c|c|c|c|c|}
\hline \multirow{2}{*}{\multicolumn{2}{|c|}{1,00}} & \multicolumn{2}{|c|}{$\begin{array}{l}\text { Cross- } \\
\text { tabulation }\end{array}$} & \multirow{3}{*}{$\begin{array}{c}\text { Value / } \\
\text { range } \\
5\end{array}$} & \multirow{3}{*}{$\begin{array}{c}\begin{array}{c}\text { Correla- } \\
\text { tion } \\
\text { coeffi- } \\
\text { cient }\end{array} \\
6\end{array}$} & \multirow{3}{*}{$\begin{array}{c}\text { Value } \\
7 \\
\end{array}$} \\
\hline & & \multirow{2}{*}{$\frac{2,00}{3}$} & \multirow[b]{2}{*}{4} & & & \\
\hline 1 & 2 & & & & & \\
\hline \multirow{3}{*}{$\begin{array}{l}\text { 2. I believe that the "school mediation" method has helped } \\
\text { to reduce the number of sanctions (punishments, bans) at } \\
\text { my school }\end{array}$} & Group 1 & 2 & 86 & & & \\
\hline & Group 2 & 8 & 32 & & & \\
\hline & Total & 10 & 118 & 0,306 & 0,293 & ,001 \\
\hline \multirow{3}{*}{$\begin{array}{l}\text { 3. The "school mediation" method has increased the re- } \\
\text { spect among the peers }\end{array}$} & Group 1 & 63 & 25 & & & \\
\hline & Group 2 & 7 & 33 & & & \\
\hline & Total & 70 & 58 & 0,504 & 0,450 &, 000 \\
\hline \multirow{3}{*}{$\begin{array}{l}\text { 4. The "school mediation" method encourages the dia- } \\
\text { logue between the peers }\end{array}$} & Group 1 & 87 & 1 & & & \\
\hline & Group 2 & 8 & 32 & & & \\
\hline & Total & 95 & 33 & 0,836 & 0,641 &, 000 \\
\hline \multirow{3}{*}{$\begin{array}{l}\text { 5. Due to the "school mediation" method the relations be- } \\
\text { tween students and teachers have improved }\end{array}$} & Group 1 & 0 & 88 & & & \\
\hline & Group 2 & 8 & 32 & & & \\
\hline & Total & 8 & 120 & 0,383 & 0,358 &, 000 \\
\hline \multirow{3}{*}{$\begin{array}{l}\text { 7. The "school mediation" method allowed resolving small } \\
\text { conflicts that would eventually turn into more serious } \\
\text { problems }\end{array}$} & Group 1 & 87 & 1 & & & \\
\hline & Group 2 & 31 & 9 & & & \\
\hline & Total & 118 & 10 & 0,369 & ,346 &, 000 \\
\hline \multirow{3}{*}{$\begin{array}{l}\text { 8. Since my school started using the "school mediation" } \\
\text { method, the teachers can better teach their subjects }\end{array}$} & Group 1 & 64 & 24 & & & \\
\hline & Group 2 & 16 & 24 & & & \\
\hline & Total & 80 & 48 & 0,313 & 0,299 &, 000 \\
\hline \multirow{3}{*}{$\begin{array}{l}\text { 11. The "school mediation" method has helped me learn to } \\
\text { communicate better }\end{array}$} & Group 1 & 62 & 26 & & & \\
\hline & Group 2 & 8 & 32 & & & \\
\hline & Total & 70 & 58 & 0,470 & 0,425 &, 000 \\
\hline \multirow{3}{*}{$\begin{array}{l}\text { 12. Thanks to mediation, I realized my guilt and am ready } \\
\text { to eliminate the damage caused }\end{array}$} & Group 1 & 1 & 87 & & & \\
\hline & Group 2 & 32 & 8 & & & \\
\hline & Total & 33 & 95 & 0,836 & 0,641 &, 000 \\
\hline \multirow{3}{*}{ 13. I am satisfied with the mediation process } & Group 1 & 64 & 24 & & & \\
\hline & Group 2 & 16 & 24 & & & \\
\hline & Total & 80 & 48 & 0,313 & 0,299 &, 000 \\
\hline \multirow{3}{*}{$\begin{array}{l}\text { 14. It is through mediation that I have learned to listen to } \\
\text { others better }\end{array}$} & Group 1 & 62 & 26 & & & \\
\hline & Group 2 & 8 & 32 & & & \\
\hline & Total & 70 & 58 & 0,470 & 0,425 &, 000 \\
\hline \multirow{3}{*}{$\begin{array}{l}\text { 15. The "school mediation" method has helped me learn to } \\
\text { recognize and express my feelings }\end{array}$} & Group 1 & 64 & 24 & & & \\
\hline & Group 2 & 8 & 32 & & & \\
\hline & Total & 72 & 56 & 0,493 & 0,442 &, 000 \\
\hline \multirow{3}{*}{$\begin{array}{l}\text { 16. The "school mediation" method has helped me to know } \\
\text { others better }\end{array}$} & Group 1 & 63 & 25 & & & \\
\hline & Group 2 & 16 & 24 & & & \\
\hline & Total & 79 & 49 & 0,301 & 0,288 &, 001 \\
\hline
\end{tabular}


Continued Table 2

\begin{tabular}{|c|c|c|c|c|c|c|}
\hline 1 & 2 & 3 & 4 & 5 & 6 & 7 \\
\hline \multirow{3}{*}{$\begin{array}{l}\text { 17. The "school mediation" method allowed me to get to } \\
\text { know myself better }\end{array}$} & Group 1 & 3 & 85 & & & \\
\hline & Group 2 & 17 & 23 & & & \\
\hline & Total & 20 & 108 & 0,499 & 0,447 &, 000 \\
\hline \multirow{3}{*}{$\begin{array}{l}\text { 18. The "school mediation" method has helped me com- } \\
\text { municate with others better }\end{array}$} & Group 1 & 63 & 25 & & & \\
\hline & Group 2 & 15 & 25 & & & \\
\hline & Total & 78 & 50 & 0,324 & 0,308 &, 000 \\
\hline \multirow{3}{*}{$\begin{array}{l}\text { 19. Through mediation I have been considering various } \\
\text { ways of conflict resolution }\end{array}$} & Group 1 & 4 & 84 & & & \\
\hline & Group 2 & 8 & 32 & & & \\
\hline & Total & 12 & 116 & 0,246 & 0,239 &, 005 \\
\hline \multirow{3}{*}{$\begin{array}{l}\text { 21. The "school mediation" method has helped me to be } \\
\text { more respectful towards others }\end{array}$} & Group 1 & 64 & 24 & & & \\
\hline & Group 2 & 8 & 32 & & & \\
\hline & Total & 72 & 56 & 0,493 & 0,442 &, 000 \\
\hline \multirow{3}{*}{$\begin{array}{l}\text { 22. Having become familiar with the "school mediation" } \\
\text { method, I could recommend it to a friend }\end{array}$} & Group 1 & 64 & 24 & & & \\
\hline & Group 2 & 8 & 32 & & & \\
\hline & Total & 72 & 56 & 0,493 & 0,442 &, 000 \\
\hline \multirow{3}{*}{$\begin{array}{l}\text { 23. The skills I have acquired through mediation can be } \\
\text { applied to other situations in my life (family, friends ...) }\end{array}$} & Group 1 & 63 & 25 & & & \\
\hline & Group 2 & 8 & 32 & & & \\
\hline & Total & 71 & 57 & 0,481 & 0,434 &, 000 \\
\hline \multirow{3}{*}{ 24. I would like to see more mediation in society } & Group 1 & 2 & 86 & & & \\
\hline & Group 2 & 8 & 32 & & & \\
\hline & Total & 10 & 118 & 0,306 & 0,293 &, 001 \\
\hline \multirow{3}{*}{$\begin{array}{l}\text { 29. Have you ever been in an unpleasant situation as a re- } \\
\text { sult of your behaviour? }\end{array}$} & Group 1 & 25 & 63 & & & \\
\hline & Group 2 & 0 & 40 & & & \\
\hline & Total & 25 & 103 & 0,332 & 0,315 &, 000 \\
\hline \multirow{3}{*}{$\begin{array}{l}\text { 30. Do you tend to violate the rules and regulations ad- } \\
\text { opted in your immediate environment (family, school ...) }\end{array}$} & Group 1 & 26 & 62 & & & \\
\hline & Group 2 & 0 & 40 & & & \\
\hline & Total & 26 & 102 & 0,340 & 0,322 &, 000 \\
\hline
\end{tabular}

There are no significant differences in the points of evaluating the impact the school mediation service has on reducing conflict at school (point 6). Both groups believe that introduction of the school mediation service did not reduce conflicts at school, but, in the opinion of group 2, it allowed for the resolution of small conflicts that would eventually become more serious problems. This evaluation might be related to an increased focus on conflicts.

The mediation method is also regarded as a good technology for increasing the skills of constructive interpersonal communication in group 2 (points 11, 14, 18). The participants who study at schools with mediation services report that their communication skills and ability to listen to the interlocutor have improved. It is worth while emphasizing a significant difference between the groups as per the parameter of respect for the interlocutor (the correlation coefficient is 0.000 ). The participants with some experience in the work of the mediation service have learned to treat the interlocutor more respectfully in a conflict situation, which is extremely important for the formation of conflict competence. The participants of group 
2 also appreciate the role of the school mediation service in establishing the safety of the educational environment and the school microclimate, which improves the quality of the learning process. A significant difference is observed in the correlation coefficient for point $8(0.00)$ - "teachers can better teach their subjects".

The respondents of group 2 note an improvement of their ability of self-understanding and that of regulating their own emotions (points 15,17 ). The ability to recognize and express their feelings and self-understanding has also improved. This is consistent with the researches by Masharova (2019), Pérez-Albarracín \& Fernández-Baena (2019), Iriarte \& Ibarrola-García (2018).

There are also certain differences between the groups in the ability to use conflict resolution skills (point 23) in other areas of life (family, friends...). The revealed difference with the correlation coefficient of 0.000 may mean a stronger ability to transfer the acquired skill to other areas of life, which also indicates some improvement of an adolescent's competence of interpersonal interaction. Point 24 on the desirability of improving mediation in the society also reveals a significant difference between these groups. However, despite the marked differences, both groups note the need to increase mediation in various areas of social interaction.

As for points $25,26,27,28$, there is no significant difference between the participants in the groups. Almost all the participants gave positive responses to the questions concerning the propensity to violate legal norms and rules (point 25), risky behaviour (point 26) and experience of using alcohol and/or drugs (point 27). There is also no difference in the participants' involvement in smoking (point 28). This is the sign of homogeneity of the sample across the groups of the participants and some features of deviance. However, there is some differentiation between points 29 and 30. Answering the questions "Have you ever been in an unpleasant situation as a result of your behaviour?" and "Do you tend to violate the rules and regulations adopted in your immediate environment (family, school, ...)?", all the participants in group 2 noted that there were troubles in their lives related to the consequences of their actions caused by violation of rules and norms. This may be due to a higher level of awareness in adolescents' behaviour and an increased ability to recognize the consequences of their actions.

\section{Conclusion}

The research of the students' perception of the effectiveness of the school mediation service results in some conclusions.

The views on the effectiveness of the mediation service are differentiated depending on whether the student has directly experienced the work of the service. The students who have been directly involved in the school mediation service evaluate it positively as the service contributing to the management of emerging conflicts, which is consistent with the researches by Villanueva, Usó \& Adrián (2013), Hansberry \& Hansberry (2018).

It should be noted that monitoring the mediation service activities from the outside does not make it possible to evaluate its effectiveness, since many students have distorted expectations of the mediation service as leading to a reduced number of sanctions against them. In addition, many deviant adolescents are sensitive to justice that distorts the views on the expected effects of mediation. In this context, we suggest that involvement in school mediation and changing the students' views on justice, linked to their focus on universal social justice, will result in the adjustment of expectations in the direction of realism of the latter.

A complex issue is the ability to transfer the skills acquired in the mediation process to other environments, but the reasons for the difficulties are currently not properly clear and require further research.

The effectiveness of the mediation service in the improvement of the skills of interpersonal relations among the participants in conflict resolution can be regarded as a positive conclusion. There is a significant improvement in the ability to self-knowledge and self-understanding, which is one of the functions of mediation. The participants involved in mediation processes are ready to recommend this service to 
their friends, which is consistent with numerous researches abroad.

Thus, the work of the school mediation service is not only a technology for reducing conflict. It is also aimed at reducing the person's infantilism, its signs being children's expectations of reducing sanctions for inappropriate behaviour and a more loyal attitude on the part of teachers, inability to transfer experience, a distorted desire for justice and perception of conflict from the aspect of guilt.

Promising research areas related to the need to form a culture of mediation in educational communities are highlighted.

\section{References}

Amador Buenabad, N.G., Ramos, R., Schwartz, S., Gutiérrez, L.M., Juárez, A., Gallegos, A., González, O.T., Pérez, L., Medina-Mora, M., Domenech Rodríguez, M. \& Villatoro Velazquez, J. (2019). Cluster Randomized Trial of a Multicomponent School-Based Program in Mexico to Prevent Behavioral Problems and Develop Social Skills in Children. In Child and Youth Care Forum, 49, 343-364. DOI: 10.1007/s10566-01909535-3.

Andronnikova, O.O., Radzikhovskaya, O.E. (2020). Victimological Aspects of the Development of Restorative Mediation Practices in a Multicultural Society: Problems, Needs, Development Prospects. In J. Sib. Fed. Univ. Humanit. Soc. Sci., 13(2), 158-166. DOI: 10.17516/1997-1370-0547.

Astanina, N.B. (2017). Justice Sensitivity and Mental Well-Being among Male Juvenile Offenders. In Clinical Psychology and Special Education, 6(1), 33-47. DOI: 10.17759/cpse.2017060103

Avdulova, T.P. (2015). Representations of Fairness in Adolescents Who Are Brought up without Parents. In Clinical Psychology and Special Education, 4(1), 29-47.

Belonogova, E.V., Prokopyeva, N.G. (2020). Algorithms for Mediative Restorative Work of the Territorial Reconciliation Service in Difficult Cases. In J. Sib. Fed. Univ. Humanit. Soc. Sci., 13(2), 179-190. DOI: 10.17516/1997-1370-0549.

Bonell, C., Allen, E., Opondo, C., Warren, E., Elbourne, D.R., Sturgess, J., Bevilacqua, L., McGowan, J., Mathiot, A., \& Viner, R.M. (2019). Examining Intervention Mechanisms of Action Using Mediation Analysis Within a Randomised Trial of a Whole-School Health Intervention. In Journal of Epidemiology and Community Health, 73(5), 455-464. DOI: 10.1136/jech-2018-211443

Boulton, M.\&Boulton, R.(2011). Resistant to the Message: Are Pupils Unreceptive to Teachers' Anti-Bullying Initiatives and if so Why? In Educational Studies, 38(5), 485-489. DOI: 10.1080/03055698.2011.643112

García-Raga, L., Grau, R., \& López-Martín, R. (2017). Mediation as a Process for the Management of Conflict and the Improvement of Coexistence in Educational Centres. A Study Based on the Perceptions of Secondary School Students. In Procedia - Social and Behavioral Sciences, 237, 465-470. DOI: 10.1016/j. sbspro.2017.02.091

García-Raga, L., Bo Bonet, R.M., \& Boqué Torremorell, M.C. (2016). Percepción del alumnado de Educación Secundaria sobre la mediación escolar en Castellón y Valencia. In Revista Complutense De Educación, 28(2), 537-554. DOI: 10.5209/rev RCED.2017.v28.n2.49581

García-Raga, L., Chiva Sanchís, I., Moral Mora, A., \& Ramos Santana, G. (2016). Fortalezas y debilidades de la mediación escolar desde la perspectiva del alumnado de educación secundaria. In Pedagogia Social Revista Interuniversitaria, 28, 203-215. DOI:10.7179/PSRI_2016.28.15.

García-Raga, L., Grau Vidal, R., \& Boqué Torremorell, M.C. (2019). School Mediation under the Spotlight: What Spanish Secondary Students Think of Mediation [Mediazione scolastica sotto i riflettori: quali studenti secondari spagnoli pensano alla mediazione]. In Journal of Educational, Cultural and Psychological Studies, 19, 41-60. DOI: 10.7358/ecps-2019-019-garc

Gong, T., Ren, Y., Wu, J., Jiang, Y., Hu, W., \& You, J. (2019). The Associations Among Self-Criticism, Hopelessness, Rumination, and NSSI in Adolescents: A Moderated Mediation Model. In Journal of Adolescence, 72, 1-9. DOI: 10.1016/j.adolescence.2019.01.007

Hansberry, B. \& Hansberry, C.L. (2018). How to Do Restorative Peer Mediation in Your School. London, Jessica Kingsley Publishers, 160 p. 
Iriarte, C., Ibarrola-García, S. (2018). Capacitación socioafectiva de alumnos y profesores a través de la mediación y la resolución de conflictos. In Padres y Maestros/Journal of Parents and Teachers, 373, 22-27. DOI:10.14422/pym.i373.y2018.003.

Khabibullin, I.R. (2018). Mediatsiia kak effektivnaia tekhnologiia razresheniia shkol'nykh konfliktov. Molodezhnye issledovaniia $\mathrm{v}$ psikhologicheskoi nauke i praktike [Mediation as an Effective Technology for Resolving School Conflicts. Youth Studies in Psychological Science and Practice]. Sborniknauchnykh statei Mezhdunarodnogo nauchno-prakticheskogo seminara [Collection of scientific articles of the International scientific-practical seminar]. Ufa: BGPU im. M. Akmully, 230-234.

Lee, D.B., Hsieh, H.F., Stoddard, S.A., Heinze, J.E., Carter, P.M., Goldstick, J.E. Cunningham, M.C., Cunningham, R.M. \& Zimmerman, M.A. (2020). Longitudinal Pathway from Violence Exposure to Firearm Carriage Among Adolescents: The Role of Future Expectation. In Journal of Adolescence, 81, 101-113. DOI:10.1016/j.adolescence.2020.03.009.

Li, X., Luo, X., Zheng, R., Jin, X., Mei, L., Xie, X., Gu, H., Hou, F., Liu, L., Luo, X., Meng, H., Zhang, J., \& Song, R. (2019). The Role of Depressive Symptoms, Anxiety Symptoms, and School Functioning in the Association Between Peer Victimization and Internet Addiction: A Moderated Mediation Model. In Journal of Affective Disorders, 256, 125-131. DOI:10.1016/j.jad.2019.05.080

Lozano-Martín, A.M., Gutiérrez-Extremera, P., Martínez-Martín, R. (2018). La mediación educativa como Cultura de paz. In Revista de Cultura de Paz, 2, 125-145.

Masharova, T.V., (2019). Mediatsiia kak sredstvo po razresheniiu konfliktov v sovremennoi obrazovatel'noi srede [Mediation as a means of resolving conflicts in the modern educational environment]. In Mir nauki, kultury, obrazovaniya [World of Science, Culture, Education], 4(77), 62-66.

Munné, M. \& Mac-Cragh, P. (2006). Los diez principios de la cultura de mediación. Barcelona: Graó. $147 \mathrm{p}$.

Nartova-Bochaver, S.K., \& Astanina, N.B. (2014). Psikhologicheskie problemy spravedlivosti v zarubezhnoi personologii: teorii i empiricheskie issledovaniia [Theories and empirical researches on justice in the foreign personality psychology]. In Psikhologicheskii Zhurnal [Psychological Journal], 35 (1), 16-32.

Pérez-Albarracín, A. \& Fernández-Baena, J. (2019). Más allá de la resolución de conflictos: Promoción de aprendizajes socioemocionales en el alumnado mediador. In Electronic Journal of Research in Education Psychology, 17(2), 335-358. DOI:10.25115/ejrep.v17i48.2223.

Puig-Gutiérrez, M. \& Morales-Lozano, J.A. (2015). La formación de ciudadanos: conceptualización y desarrollo de la competencia social y cívica [The Training of Citizens: Conceptualisation and Development of the Social and Civic Competence]. In Educación XX1, 18 (1), 259-282. DOI: 10.5944/educXX1.18.1.12332

Pulido, R., Martín-Seoane, G. \& Lucas-Molina, B. (2013). Orígenes de los Programas de Mediación Escolar: Distintos enfoques que influyen en esta práctica restaurativa [The Origins of School Mediation Programmes: Different Approaches that Have an Impact in this Restorative Practise]. In Anales de Psicología, 29 (2), 385-392. DOI: 10.6018/analesps.29.2.132601

Sezen, B., \& Bedel, A. (2015). The Investigation of the Effect of Negotiation and Mediation Training on Interpersonal Problem Solving Approaches and Anger of Adolescents. In Egitim ve Bilim, 40, 63-75. DOI:10.15390/EB.2015.4816

Sudakova, T.M., Koryagina, S.A. (2017). Mediativnye tekhnologii v rannem i neposredstvennom preduprezhdenii prestupnogo povedeniia shkol'nikov [Mediation Technologies in Early and Direct Prevention of Criminal Behavior of Schoolchildren]. In Izvestiia Baikal'skogo gosudarstvennogo universiteta [Bulletin of Baikal State University], 27(3), 425-433. DOI: 10.17150/2500-2759.2017.27(3).425-433

Tucker, E. \& Maunder, R. (2015). Helping Children to Get Along: Teachers' Strategies for Dealing with Bullying in Primary Schools. In Educational Studies, 41(4). DOI: 10.1080/03055698.2015.1043980

Villanueva, L., Usó, I. \& Adrián, J.E. (2013). Los programas de mediación entre iguales: una herramienta eficaz para la convivencia escolar [Peer Mediation Programmes: an Effective Tool for School Coexistence]. In Apuntes de Psicología, 31 (2), 165-171. 


\section{Специфика отношения к}

\section{к школьной службе медиации учеников}

\section{с девиантным поведением}

\section{О.О.Андронникова, О.Е. Радзиховская}

Новосибирский государственный педагогический университет

Российская Федерация, Новосибирск

Аннотация. В данной статье рассматриваются вопросы восприятия эффективности школьных служб медиации подростками с девиантным поведением. Исследование проведено на русскоязычной выборке подростков в возрасте 13-17 лет (128 испытуемых, из них 78 девушек и 50 юношей). Анкета разработана на основе аналогичных исследований с использованием экспертной оценки. Результаты исследования проанализированы при помощи коэффициента сопряженности Пирсона. Анализ разницы в восприятии эффективности практик медиации группой, непосредственно участвующей в реализации практик медиации (40 человек - группа 2), и группой, не имеющей непосредственного опыта медиации (88 человек - группа 1), позволил сделать ряд выводов. По мнению участников группы 2, метод медиации выступает эффективным средством решения конфликтов, увеличения навыков межличностного взаимодействия и уважительного отношения к собеседнику. Также медиация является эффективным средством саморазвития и самопонимания для участников группы 2. В группе 1 наблюдаются инфантильные ожидания эффектов медиации и высокая чувствительность к справедливости.

Ключевые слова: медиация, девиантное поведение, подростки, межличностные отношения, конфликтная компетентность, виктимизация, образование.

Научная специальность: 13.00.00 - педагогические науки. 